\title{
Trend Analysis of Red Chili Price-Formation Models
}

\author{
Siti Mir'atul Khasanah, Mochammad Maksum, Endy Suwondo* \\ Agro-Industrial Technology Department, Faculty of Agricultural Technology, \\ Universitas Gadjah Mada, Jl. Flora No. 1, Bulaksumur, Yogyakarta 55281, Indonesia \\ ${ }^{*}$ Correspondence author: Endy Suwondo, E-mail: endys@ugm.ac.id
}

Received: May 20, 2019; Accepted: October 21, 2019

\begin{abstract}
Red chili's characteristic flavor has been a popular element in Indonesian cuisine. A large and continuous demand for red chili is inconsistent with production volumes, causing frequent and extreme price fluctuations throughout the year. This study explores the changing trends in red chili prices to identify the influencing factors. The study was conducted in the Sleman district of Yogyakarta, Indonesia. Time-series datasets of monthly production rates and prices of chili for 3 years were subject to multiple linear regression analysis. The study found a rising trend in prices in the Sleman Regency from January 2014 to December 2016. The factors significantly influencing the red chili prices was the price of cayenne pepper. The production cost of chili, the price of tomatoes, and the price of chili for the previous 2 months had only partial and nonsignificant effects. The timing of great Muslim celebrations, such as Eid Al-Fitr and Eid Al-Adha had no significant effect on the price of red chili. However, Christmas and New Year events were associated with higher prices.
\end{abstract}

Keywords: Modeling; price formation; red chili; time-series; trend

\section{INTRODUCTION}

Indonesia has a large number of horticultural crops, including fruits, vegetables, flowers, and ornamental plants. Red chili (Capsicum annuum L.) is a vegetable used almost daily by Indonesian cooks in a wide variety of dishes. Red chili prices fluctuate according to market demand, which is affected by religious holidays (Eid AlFitr, Christmas, and New Year), seasonal cycles, and harvest periods. Red chili contains many nutrients and vitamins (Orobiyi et al., 2015), including protein, fat, carbohydrates, calcium, and vitamins A, B1, and C. Red chili is used primarily in households, but it is also used by the food, spice, herb, and medical industries (Omolo et al., 2014; Saleh et al., 2018). According to Indarti (2016), demand for chili increases by $10 \%-20 \%$ during celebrations and religious holidays. Based on data from the Ministry of Commerce in December 2014, the price of red chili contributes to national inflation due to high price fluctuations that repeat annually.

On Java Island, red chili is produced primarily in east, west, and central Java. Production growth from these regions is depicted in Table 1. East Java produces twice as much as west Java, with the result that red chili prices in Jakarta (a city closer to west Java) are typically higher than those in Surabaya (the provincial capital of east Java). However, both cities experience similar patterns in price fluctuations. Indarti (2016) reported such a pattern from 1998 to the end of 2010. A review of monthly retail prices on the island of Java shows that the red chili market is highly integrated. Prices in one region or city are closely related to prices in other regions.

From 2010 to 2014 the price of red chili at the producer and consumer levels experienced a sharp surge. The price of red chili at the producer level in 2010 was Rp16,343 per $\mathrm{kg}$ and in 2014 it reached Rp19,237 per $\mathrm{kg}$, while the consumer prices were Rp31,260 per $\mathrm{kg}$ and Rp44,519 per kg, respectively (Indarti, 2016). Toward the end of the year and until the beginning of the following year, the price of red chili can surge to Rp100,000 per kg, but also fall to less than Rp10,000 per $\mathrm{kg}$. These seasonal price fluctuations occur almost every year. Surges in chili prices are thought to be caused by declines in supply while consumption remains constant and continuous or increases in certain periods, such as long holidays. These fluctuations are thought 
Table 1. Red chili production on Java in 2011-2015

\begin{tabular}{llcccccc}
\hline \multirow{N}{N}{} & Province & \multicolumn{7}{c}{ Production (tons) } & \multirow{2}{*}{ Average (ton) } \\
\cline { 3 - 6 } & & 2011 & 2012 & 2013 & 2014 & 2015 & 228.432 \\
\hline 1 & East Java & 181.806 & 244.040 & 227.486 & 238.820 & 250.007 & 109.596 \\
2 & West Java & 105.237 & 90.522 & 123.756 & 115.831 & 112.634 & 98.706 \\
3 & Central Java & 65.227 & 84.997 & 85.361 & 107.963 & 149.990 & \\
\hline
\end{tabular}

to be caused by changes in seasonal chili production volumes, rainy season conditions, production costs, and the length of distribution channels (Farid and Subekti, 2012; Zulfitriyana et al., 2016).

Two main problems are common in the red chili market: price fluctuation and price disparities between regions (Viana et al., 2017). These conditions can drive inflation, as in September 2016, where red chili prices rose $18 \%$ compared with the previous month, leading to an increase in the inflation rate to $0.22 \%$ from $-0.02 \%$ the previous month. Cumulatively, inflation during the running calendar year can reach $1.97 \%$ (Anonymous, 2017).

The objective of this study was to learn more about the price changes and trends by identifying the factors affecting the changes. Through analysis of these factors and their role in price formation, it is hoped that future price fluctuations can be anticipated. A review of previous studies suggests that the price of chili is influenced by prices for substitute and complementary goods, chili prices in previous periods, the amount of red chili produced, and major holiday celebrations.

Substitute goods are those that can replace primary goods when the latter are hard to find or too expensive. In this study, cayenne pepper was used as a substitute for chili, as suggested by Palar et al. (2016).

Wei et al. (2018) reported that two complementary products fetch the same optimal wholesale/retail prices, maximum retail margins, and maximum demands regardless of the manufacturers' cooperation or noncooperation strategies. As Indonesian consumers tend to prefer a meal with red chili sauce in which tomatoes are almost always included, tomatoes are considered a supplementary material and its price needs to be taken into account as well.

Red chili price fluctuations are significantly influenced by price fluctuations in previous periods. The greater the price fluctuations of red chili in a previous period, the greater the price fluctuations in in the current period. An analysis of factors affecting the price of red chili in East Java by Webb and Kosasih (2011) found that the price of red chili in previous months had a significant effect on current prices.
The price of red chili also depends on the amount of red chili produced, which depends in turn on the total area harvested and the productivity of the land. According to Aryasita and Mukarromah (2013) the amount of red chili available throughout the year has changed due to extensive fluctuations in total area harvested and red chili production.

Red chili price fluctuations follow market demand. In the days leading up to the Feast of Eid Al-Fitr and Christmas, the price of chili usually increases.

\section{Price Change Trends}

In simple terms, price trends for red chili can be estimated using an adaptation of a linear regression method on time-series data (Equation 1).

$$
Y=a+b X
$$

where:

$$
\begin{aligned}
Y= & \text { red chili price as the dependent variable } \\
& (\mathrm{Rp} / \mathrm{kg}) \\
a= & \text { constant/intercept } \\
b= & \text { coefficient/slope } \\
X= & \text { month/case sequence as an independent } \\
& \text { variable }
\end{aligned}
$$

If a price relationship over time shows an increasing trend, the price of red chili in the future is estimated to be higher. But if the trend fluctuates or declines, there is a tendency for the consumption pattern to be unstable. Trend analysis is used with a view to measuring the development of red chili prices change from time to time.

Fluctuations or risks of red chili prices are significantly affected by fluctuations or risks of red chili prices in the previous period. The higher the fluctuation of red chili prices in the previous period, the higher the fluctuation or risk of red chili prices in the current period. Meanwhile, the current supply of red chili has a significant effect on fluctuations in red chili prices. Regulation of the market through price references according to Sativa et al. (2017) did not significantly affect prices.

To analyze the factors that influence the price of red chili, a multiple regression analysis (Equation 2) 
can be applied. Turvey (2016) used an autoregressive approach to modeling commodity prices, while $\mathrm{He}$ and Chen (2010) implemented multifractal detrended crosscorrelation analysis to predict the futures market of a general agricultural product. The model formulation of multiple regression is similar to single regression, except that independent variables and accompanying coefficients are added. Using computer technology, multiple regression calculations are easy and fast, even with many variables and extensive datasets.

$$
Y=a+b_{1} X_{1}+b_{2} X_{2}+\ldots+b_{n} X_{n}+\varepsilon_{i}
$$

where:

$Y=$ red chili price trend as dependent variable

$a=$ constant/intercept

$b=$ coefficient/slope

$X=$ factors using as independent variable

$\varepsilon_{\mathrm{i}}=$ errors that are normally distributed with zero mean

Multiple regression analysis is applied when more than one variable is involved, so it is included in the multivariate analysis class. However, if the relationship between one independent variable $X$ and the dependent variable $Y$ when $X$ is considered constant, then a least squares method can be used. Multiple regression analysis can therefore be used a bridge between simple bivariate regression analysis and multivariate regression analysis.

The classic assumption test is a statistical requirement that must be met in ordinary least square (OLS)-based linear regression analysis. Regression analysis that is not based on OLS does not need classical assumptions, such as logistic regression conducted by Díaz-Pérez (2019). Likewise, not all classic assumption tests must be carried for a linear regression analysis. For example, multicollinearity tests cannot be used in simple linear regression analyses and autocorrelation tests do not need to be applied to cross-sectional data. At least four classic assumption tests are available: multicollinearity, heteroscedasticity, normality, and autocorrelation (Ansofino et al., 2016).

Assumptions that must be fulfilled by the multiple linear regression equation include (1) normality (classical linear regression assumes that every $\varepsilon_{i}$ follows a normal distribution), (2) non-autocorrelation between sides, with covariance equaling zero, (3) homoschedasticity, in which the variance of all residuals is constant, and (4) no multicollinearity, or no perfect linear relationship between variables.

\section{RESEARCH METHODS}

The study was conducted from May to September 2017. Primary data were collected through interviews with farmers, businesspeople, and the Regency Agriculture Service of Sleman District. The data collected were red chili production, prices at the farmer level, and the price of tomatoes as a supplement of red chili. All the data consist of monthly records from January 2014 to December 2016. Special attention was given to the data for the weeks before Eid Al-Fitr, Christmas, and New Year.

Analysis of red chili price trends for 36 months was carried out using trend analyses based on linear regression of Eq. (1) and Eq. (2) using SPSS Application. In this test the following hypothesis was used:

$H_{0}=$ There is no trend element
$H_{1}=$ There is a trend element

Decision-making criteria:

Confidence level $=90 \%$

The margin of error $\left(\varepsilon_{\mathrm{i}}\right)=10 \%$

Significance $t<0.05 ; H_{0}$ is rejected

Significance $t>0.05 ; H_{0}$ is accepted

In building the price-formation model, the factors that were taken into account that affect the price of red chili were red chili prices at the producer level, the price of red chili from the previous month, chili supply volume, and community cultural factors around major days of celebration.

\section{RESULTS AND DISCUSSION}

\section{Trend Analysis of Price Changes of Red Chili}

Analysis of trends of chili prices was performed so that fluctuations in the price of chili could be anticipated.

Table 2. Prices of red chili at the farmer level in Sleman Regency (Rp/kg)

\begin{tabular}{crrr}
\hline \multirow{2}{*}{ Month } & \multicolumn{3}{c}{ Year } \\
\cline { 2 - 4 } & \multicolumn{1}{c}{2014} & \multicolumn{1}{c}{2015} & \multicolumn{1}{c}{2016} \\
\hline January & 20,336 & 17,923 & 12,763 \\
February & 19,371 & 16,591 & 16,991 \\
March & 12,866 & 13,762 & 22,518 \\
April & 9,764 & 13,379 & 13,145 \\
May & 6,839 & 12,822 & 12,136 \\
June & 4,908 & 13,931 & 12,521 \\
July & 6,034 & 14,900 & 13,724 \\
August & 8,532 & 20,634 & 17,704 \\
September & 15,651 & 15,441 & 17,777 \\
October & 13,830 & 5,007 & 29,617 \\
November & 32,207 & 5,229 & 39,192 \\
December & 43,724 & 43,724 & 41,009 \\
\hline
\end{tabular}


Tabel 3. Regression result of trend component of red chili price fluctuations

\begin{tabular}{|c|c|c|c|c|c|}
\hline \multicolumn{6}{|c|}{ Coefficients } \\
\hline & \multicolumn{2}{|c|}{$\begin{array}{l}\text { Unstandardized } \\
\text { coefficients }\end{array}$} & \multirow{2}{*}{$\begin{array}{c}\begin{array}{c}\text { Stan } \\
\text { dardized } \\
\text { coefficients }\end{array} \\
\text { Beta }\end{array}$} & \multirow{2}{*}{$t$} & \multirow{2}{*}{ Sig. } \\
\hline & B & $\begin{array}{l}\text { Std. } \\
\text { error }\end{array}$ & & & \\
\hline $\begin{array}{l}\text { Case } \\
\text { Sequence }\end{array}$ & 321 & 162 & 0,321 & 1,975 & 0,056 \\
\hline (Constant) & 11747 & 3446 & & 3,409 & 0,002 \\
\hline
\end{tabular}

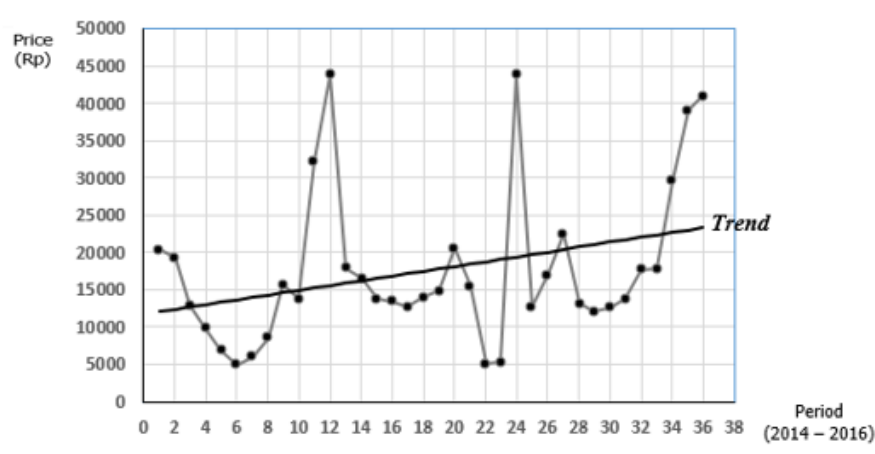

Figure 1. Trends in red chili prices at the farmer level in Sleman Regency.
A time-series of red chili prices is shown in Table 2, regression results are presented in Table 3, and the resulting trends are displayed in Figure 1.

The results reveal a trend in red chili prices at the farmer level in Sleman Regency. The trend can be expressed by $Y=11,747+321 X$. The results of the analysis (Figure 1) show that the trend line has an increasing tendency. That indicates that overall the price of red chili increased from year to year.

\section{Analysis of Factors Affecting Changes in Chili Prices}

The factors that influenced changes in chili prices were analyzed using multiple linear regression analysis. The analyzed time-series data are presented in Table 4 and the results are provided in Table 5. As expected, high demand for red chili ahead of a celebration of a religious holiday is associated with an increase in the price of red chili. However, data for three years (2014-2016) showed no significant change in the price of red chili before and during Eid Al-Fitr, which took place in June and July of 2014 and 2016. A prominent increase in red chili prices occurred at the end of the year, when the need for red chili rose because of Christmas and New Year celebrations. Increased demand pressures accompanied by low year-end production volumes due to the rainy season is the main cause of increasing red chili prices.

Table 4. Time series data used for multiple linear regression analysis of red chili as function of red chili production, tomato price, cayenne pepper price, red chili price 2 months ago and religious holidays

\begin{tabular}{ccccccc}
\hline Month & $\begin{array}{c}\text { Red chili } \\
\text { production } \\
\text { (quintal) }\end{array}$ & $\begin{array}{c}\text { Red chili price } \\
\text { (Rp/kg) }\end{array}$ & $\begin{array}{c}\text { Tomato } \\
\text { price }\end{array}$ & $\begin{array}{c}\text { Cayenne } \\
\text { pepper price } \\
\text { (Rp/kg) }\end{array}$ & $\begin{array}{c}\text { Red chili } \\
\text { price 2 } \\
\text { months ago }\end{array}$ & $\begin{array}{c}\text { Dummy var (Eid } \\
\text { Al-Fitr, Christmas, } \\
\text { New Year) }\end{array}$ \\
\hline January & 3,344 & 20,336 & 5,473 & 19,455 & 31,550 & 1 \\
February & 4,354 & 19,371 & 4,660 & 29,962 & 40,330 & 0 \\
March & 3,280 & 12,866 & 4,813 & 28,180 & 20,336 & 0 \\
April & 2,833 & 9,764 & 4,528 & 19,853 & 19,371 & 0 \\
May & 2,964 & 6,839 & 4,396 & 8,533 & 12,866 & 1 \\
June & 3,063 & 4,908 & 4,447 & 4,913 & 9,764 & 1 \\
July & 3,683 & 6,034 & 5,647 & 6,903 & 6,839 & 0 \\
August & 2,404 & 8,532 & 4,146 & 8,432 & 4,908 & 0 \\
September & 2,091 & 15,651 & 3,556 & 11,270 & 6,034 & 0 \\
October & 3,254 & 13,830 & 3,299 & 9,197 & 8,532 & 0 \\
November & 3,162 & 32,207 & 3,795 & 25,883 & 15,651 & 0 \\
December & 3,053 & 43,724 & 4,674 & 49,688 & 13,830 & 1 \\
\hline
\end{tabular}




\begin{tabular}{|c|c|c|c|c|c|c|}
\hline Month & $\begin{array}{l}\text { Red chili } \\
\text { production } \\
\text { (quntal) }\end{array}$ & $\begin{array}{l}\text { Red chili price } \\
\text { (Rp/kg) }\end{array}$ & $\begin{array}{l}\text { Tomato } \\
\text { price }\end{array}$ & $\begin{array}{c}\text { Cayenne } \\
\text { pepper price } \\
(\mathrm{Rp} / \mathrm{kg})\end{array}$ & $\begin{array}{c}\text { Red chili } \\
\text { price } 2 \\
\text { months ago }\end{array}$ & $\begin{array}{c}\text { Rummy var (Eid } \\
\text { Al-Fitr, Christmas, } \\
\text { New Year) }\end{array}$ \\
\hline \multicolumn{7}{|c|}{2015} \\
\hline January & 9,138 & 17,923 & 46,91 & 38,104 & 32,207 & 1 \\
\hline February & 4,713 & 16,591 & 47,92 & 19,279 & 43,724 & 0 \\
\hline March & 4,313 & 13,762 & 45,35 & 20,637 & 17,923 & 0 \\
\hline April & 4,234 & 13,379 & 40,63 & 19,699 & 16,591 & 0 \\
\hline May & 4,222 & 12,822 & 40,09 & 18,168 & 13,762 & 1 \\
\hline June & 4,510 & 13,931 & 39,90 & 15,078 & 13,379 & 1 \\
\hline July & 4,049 & 14,900 & 37,00 & 15,268 & 12,822 & 0 \\
\hline August & 4,017 & 20,634 & 38,46 & 26,496 & 13,931 & 0 \\
\hline September & 3,075 & 15,441 & 33,88 & 11,650 & 14,900 & 0 \\
\hline October & 2,900 & 5,007 & 33,88 & 5,536 & 20,634 & 0 \\
\hline November & 3,185 & 5,229 & 34,54 & 5,648 & 15,441 & 0 \\
\hline December & 3,053 & 43,724 & 46,74 & 49,688 & 5,007 & 1 \\
\hline \multicolumn{7}{|c|}{2016} \\
\hline January & 2,641 & 12,763 & 27,99 & 17,418 & 5,229 & 1 \\
\hline February & 2,463 & 16,991 & 32,16 & 21,900 & 43,724 & 0 \\
\hline March & 2,890 & 22,518 & 43,22 & 30,872 & 12,763 & 0 \\
\hline April & 3,761 & 13,145 & 40,61 & 21,056 & 16,991 & 0 \\
\hline May & 3,086 & 12,136 & 38,97 & 17,718 & 22,518 & 0 \\
\hline June & 2,356 & 12,521 & 41,46 & 13,436 & 13,145 & 1 \\
\hline July & 2,649 & 13,724 & 37,05 & 15,619 & 12,136 & 1 \\
\hline August & 2,926 & 17,704 & 36,19 & 23,217 & 12,521 & 0 \\
\hline September & 3,011 & 17,777 & 36,33 & 18,337 & 13,724 & 0 \\
\hline October & 4,186 & 29,617 & 37,25 & 19,171 & 17,704 & 0 \\
\hline November & 4,598 & 39,192 & 37,25 & 28,263 & 17,777 & 0 \\
\hline December & 3,234 & 41,009 & 37,25 & 32,937 & 29,617 & 1 \\
\hline
\end{tabular}

Table 5. Results of an analysis of red chili production, tomato prices, cayenne pepper prices, red chili prices 2 months previously, and religious holidays, as factors affecting red chili price changes

\begin{tabular}{|c|c|c|c|c|c|c|c|c|c|c|c|c|}
\hline \multirow[t]{2}{*}{ Model } & \multicolumn{2}{|c|}{$\begin{array}{l}\text { Unstandardized } \\
\text { coefficients }\end{array}$} & \multirow{2}{*}{$\frac{\begin{array}{c}\text { Unstan- } \\
\text { dardized } \\
\text { coefficients }\end{array}}{\text { Beta }}$} & \multirow[t]{2}{*}{ Sig } & & \multicolumn{2}{|c|}{$\begin{array}{l}90.0 \% \text { Confi- } \\
\text { dence interval } \\
\text { for B }\end{array}$} & \multicolumn{3}{|c|}{ Correlations } & \multicolumn{2}{|c|}{$\begin{array}{l}\text { Collinearity } \\
\text { statistics }\end{array}$} \\
\hline & B & Std. Error & & & & $\begin{array}{l}\text { Lower } \\
\text { bound }\end{array}$ & $\begin{array}{l}\text { Upper } \\
\text { bound }\end{array}$ & $\begin{array}{l}\text { Zero - } \\
\text { order }\end{array}$ & Partial & Part & $\begin{array}{l}\text { Toler- } \\
\text { ance }\end{array}$ & VIF \\
\hline 1 (Constants) & 6.284 & 3.582 & & 1.754 & 0.090 & 0.205 & 12.364 & & & & & \\
\hline Red chili production & -0.002 & 0.001 & -0.174 & -1.476 & 0.150 & -0.003 & 0.000 & 0.089 & -0.260 & -0.149 & 0.734 & 1.363 \\
\hline Tomato price & 0.021 & 0.067 & 0.034 & 0.318 & 0.752 & -0.093 & 0.136 & 0.140 & 0.058 & 0.032 & 0.868 & 1.151 \\
\hline \multirow{2}{*}{$\begin{array}{l}\text { Cayenne price } \\
\text { Red chili price } 2 \\
\text { months ago }\end{array}$} & 0.840 & 0.106 & 0.871 & 7.896 & 0.000 & 0.660 & 1.021 & 0.815 & 0.822 & 0.796 & 0.835 & 1.198 \\
\hline & -0.044 & 0.116 & -0.042 & -0.376 & 0.709 & -0.241 & 0.154 & 0.102 & -0.069 & -0.038 & 0.816 & 1.226 \\
\hline $\begin{array}{l}\text { Dummy Var (Eidl Fitri, } \\
\text { Christmast, New Year) }\end{array}$ & 0.017 & 2.318 & 0.001 & 0.007 & 0.994 & -3.918 & 3.952 & 0.182 & 0.001 & 0.001 & 0.918 & 1.090 \\
\hline
\end{tabular}

a Dependent variable: red chili price 
From the analysis of factors that influence the price of red chili in Sleman Regency, it can be seen that the price of cayenne pepper significantly affected the price of red chili. Meanwhile, the amount of red chili production, tomato prices, the price of red chili 2 months before, and holidays had no significant effect. However, from the 3 consecutive years that were observed, it was clear that the increase in the price of red chili was extreme at the end of each year (December), which is the peak of the rainy season and when red chili production decreases dramatically. Low supply and high demand naturally drives up prices. Unfortunately, this happens when people need more red chili to celebrate Christmas and New Year.

From a classical assumptions test, multicollinearity, autocorrelation, heteroscedasticity and normality results can be generated. As presented in Table 5, there is no variance inflation factor of all variables greater than 5 (many references require no more than 10, but some require no more than 5 ), which indicates that there can be multicollinearity in the independent variable. Autocorrelation can be seen in the Model Summary Table of the SPSS results. Based on the Table, the Durbin-Watson value is 0.834 .

The results of the heteroscedasticity test are presented as a scatterplot (Figure 2). The point distribution did not form a particular pattern/path, indicating that heteroscedasticity did not occur or that homoscedasticity did occur. Distribution of value (represented by dots in Figure 3) from the P-P Normal image is relatively close to a straight line, meaning that residuals (data) are normally distributed.

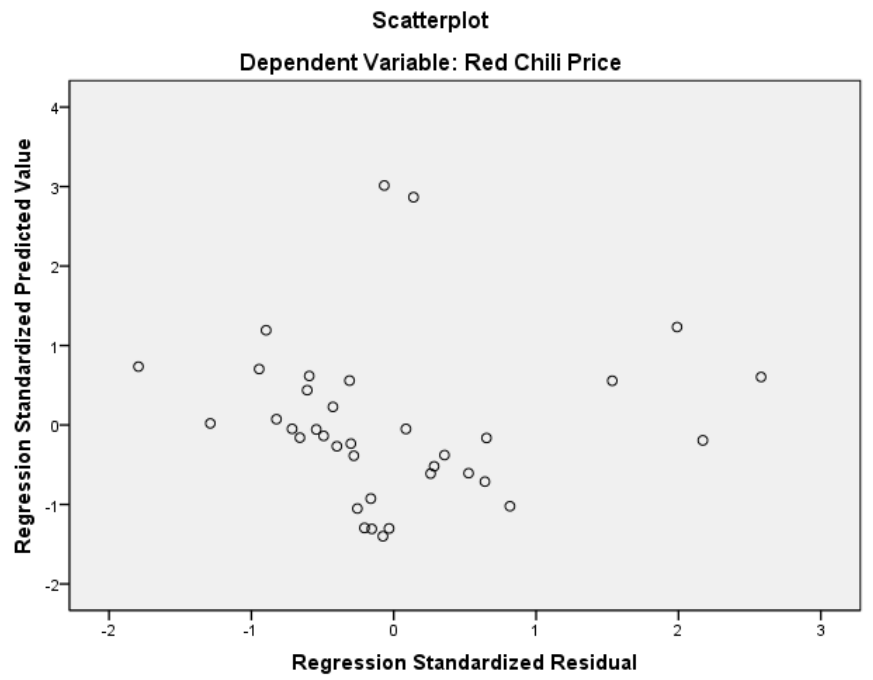

Figure 2. The results of heteroscedasticity test for red chili price

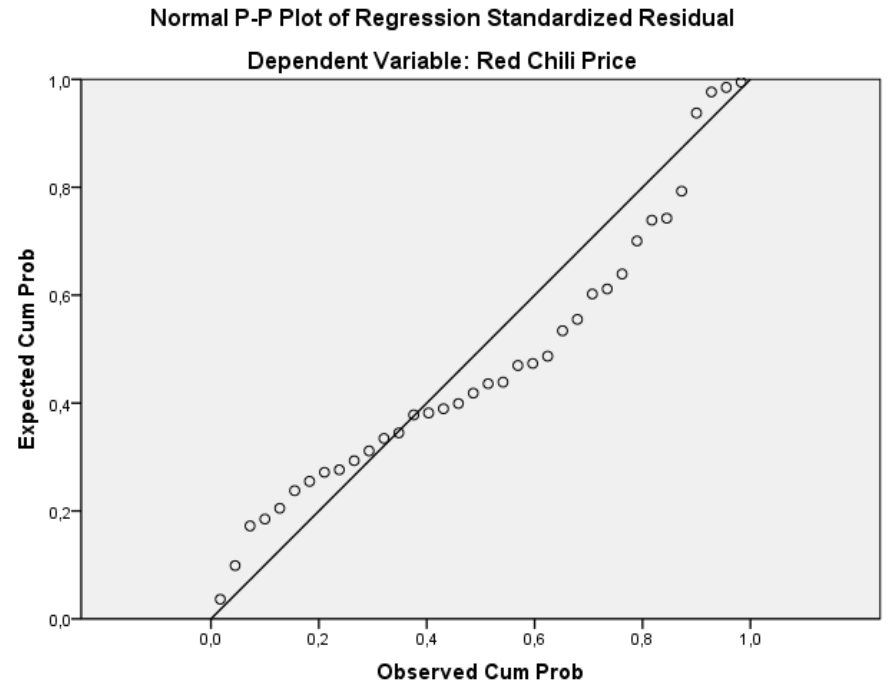

Figure 3. Normality test results for red chili price

The analysis presented in Table 5 shows that only the price of cayenne pepper significantly affected the price of red chili. Results of the analysis of the effect of cayenne pepper prices on red chili prices are shown in Figure 4. The estimated closeness of this relationship has an $R^{2}$ value of 0.664 . The strength of the influence of cayenne pepper is due to the product function factor, in which cayenne pepper is a substitution product for red chili.

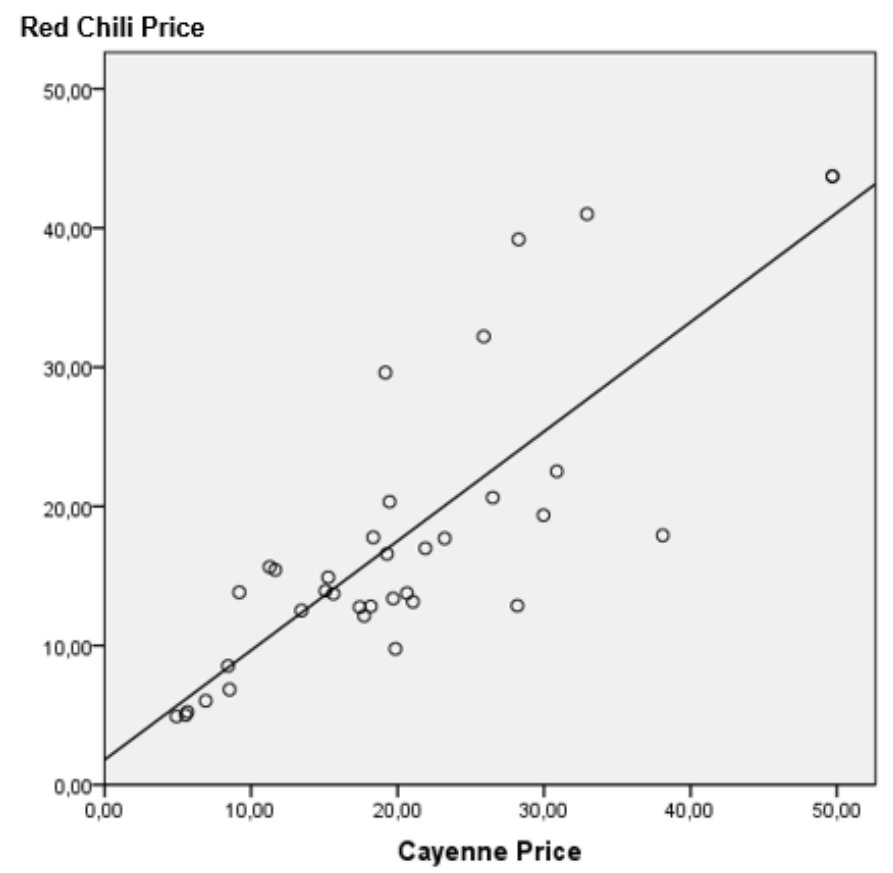

Figure 4. The effect of cayenne pepper prices on red chili prices 


\section{CONCLUSION}

The trends in red chili prices in the Sleman Regency in January 2014 to December 2016 have increased. The primary factor that significantly influenced the price of red chili in Sleman Regency is the price of cayenne peppers. The influence of red chili production, tomato prices, the prices of red chili from 2 months before, and holiday celebrations are partial and these factors had no significant effect on red chili prices, except for at the end of year.

\section{ACKNOWLEDGMENTS}

We thank the Faculty of Agricultural Technology UGM for funding this research through The Innovative Research Grant 2017.

\section{CONFLICT OF INTEREST}

The author states that this article is original research that has not been published in another journal, and that there is no conflict of interest.

\section{REFERENCES}

Anonymous(2017). Harga Cabaimerahmelonjak18\% Picuinflasi september. Accessed from https://www.cnnindonesia. com/ekonomi/20161003133521-92-162923/hargacabai-merah-melonjak-18-picu-inflasi-september/

Ansofino, Jolianis, Yolamalinda and Arfilindo, H. (2016). Textbook on Econometrics. Yogyakarta: Deepublish

Aryasita, P. R. and Mukarromah, A. (2013). Analisis fungsi transfer pada harga cabai merah yang dipengaruhi oleh curah hujan di Surabaya. J. Sains Arts POMITS, 2(2). Doi: 10.12962/j23373520.v2i2.4848

Díaz-Pérez, M., Carreño-Ortega, Á, Salinas-Andújar, J. A. and Callejón-Ferre, Á (2019). Logistic Regression to evaluate the marketability of pepper cultivars. Agronomy, 9(3). Doi: 10.3390/agronomy9030125

Farid, M. and Subekti, N. A. (2012). Tinjauan terhadap produksi, konsumsi, distribusi dan dinamika harga cabe di Indonesia. Scientific Bulletin at Research and Development Center for Trade, 6 (2). https://doi. org/10.30908/bilp.v6i2.132
Indarti, D. (2016). Outlook komoditas pertanian Sub sektor Hortikultura. Jakarta: Center for Agricultural Data and Information System. Secretariat General of the Ministry of Agriculture. ISSN: 1907-1507

Omolo, M. A., Wong, Z. Z., Mergen, A. K., Hastings, J. C., Le, N. C., Reiland, H. A., Case, K. A. and Baumler, D. J. (2014). Antimicrobial properties of chili peppers. J. Infect. Dis. Ther., 2(4). Doi: http://dx.doi.org/10.4172/23320877.1000145

Orobiyi, A., Ahissou, H., Gbaguidi, F., Sanoussi, F., Houngbèmè, A., Dansi, A. and Sanni, A. (2015). Capsaicin and ascorbic acid content in the high yielding chili pepper (Capsicum annuum L.) landraces of Northern Benin. Int. J. Curr. Microbiol. App. Sci., 4(9): 39-403. Available from http:// www.ijcmas.com

Palar, N., Pangemanan, P. A. and Tangkere, E. G. (2016). Faktor-faktor yang mempengaruhi harga cabai rawit di Manado. J. Agri-Sosioekonomi, 12(2). Doi: https://doi. org/10.35791/agrsosek.12.2.2016.1227

Saleh, B. K., Omer, A. and Teweldemedhin, B. (2018). Medicinal uses and health benefits of chili pepper (Capsicum spp.): a review. MOJFPT, 6(4): 325-328. Doi: 10.15406/ mojfpt.2018.06.00183

Sativa, M., Harianto, H. and Suryana, A. Int. J. Agr. Syst., 5(2): (2017Sativa). Doi: 10.20956/ijas.v5i2.1201

Turvey, C. G. and Wongsasutthikul, P. (2016). An autoregressive approach to modeling commodity prices as a quasifractional Brownian motion. Agric. Fin. Rev., 76(1): 5475. Doi: 10.1108/AFR-01-2016-0004

Noorviana, C. D. N., Hartono, S. and Waluyati, L. R. (2017). Volatility analysis on producer price of red pepper and cayenne pepper in west Java Province Indonesia. Agro Ekon., 28(2). https://doi.org/10.22146/jae.25939

Webb, A. J. and Kosasih, I. A. (2011). Analysis of price volatility in the Indonesia fresh chili market. Annual Meeting of the International Agricultural Trade Research Consortium. Available from https://iatrc.umn.edu/wpcontent/uploads/2011Dec-AWebb_paper.pdf

Wei, J., Wang, W., Tsai, S. B. and Yang, X. (2018). To cooperate or not? an analysis of complementary product pricing in green supply chain. Sustainability, 10(5). Doi: 10.3390/ su10051392

K. (2016). Analysis of factors affecting demand red chili pepper (Capsicum annum L) in Solok and effort fulfillment. Int. J. Sci. Technol. Res., 5(8): 159 